\title{
DIVERSITY MANAGEMENT IN THE CONTEXT OF HUMAN RESOURCES MANAGEMENT
}

\author{
Katarzyna Krysińska-Kościańska \\ Wrocław University of Economics \\ e-mail: katarzyna.krysinska-koscianska@ue.wroc.pl \\ DOI: 10.15611/noz.2017.4.02 \\ JEL Classification: M14
}

\begin{abstract}
Summary: The purpose of this article is to review the subject literature as regards the predicted challenges being faced now or in the near future by organisations in the area of diversity management. First, the author overviews the definitions of diversity and diversity management., then presents the undertaken actions that make the diversity management possible from the human resources management perspective. The theoretical study considers the terminology connected with diversity management and proposes improving solutions with respect to selected sub-functions of managing diversified employees.
\end{abstract}

Keywords: diversity, diversity management, human resources management.

\section{Introduction}

The changes taking place in the contemporary world caused, among others, by technological progress, international migrations including the ease of movement between countries and continents, or by demographic factors, are the reasons for the researchers' and practitioners' growing interest. These changes yield diversity among employees on the labour market, which is undoubtedly a challenge for the management staff [Deloitte Millennial... 2015; Deloitte Global... 2016; Trendy HR .. . 2017] aware of the significance of effective human resources management with respect to the entire company's operations. On the other hand, the man-agement of employee diversity is a key factor of competitive advantage for many entities.

The purpose of this article is to review the subject literature as regards the predicted challenges being faced now or soon by organizations in the area of diversity management. First, the author overviews the definitions of diversity and diversity management, then presents the undertaken actions that make the diversity management possible from the human resources management perspective. The theoretical study considers terminology connected with diversity management and proposes improving solutions with respect to selected sub-functions of managing diversified employees.

\section{Prognosis and challenges for companies regarding human resources management}

The authors of the report entitled Global Human Capital Trends 2016 draw attention to four key factors causing a change in the previous approach to human resources management: demographic changes, digital technology, the pace of the changes and new employee-employer relations [Deloitte Global... 2016]. Today's employees are often representatives of different generations (baby boomers, $\mathrm{X}, \mathrm{Y}, \mathrm{Z}$ generation) working together, presenting different values, attitude and expectations from work, superiors, own development and career or remuneration. A new managerial skill, namely managing the generation mix will be a challenge for managers [Martin, Tulgan 2006]. Digital technologies and the pace of changes on the other hand equip the workplace with new tools and change the manner of work performance.

Additionally, other social trends will gain significance and these include:

1. rapid human urbanisation, meaning clusters attractive from the professional carrier point of view concentrated around big cities and attracting a dispro-portionate number of well-educated and talented people, 
2. balanced man, meaning that a constantly growing percentage of men will decide on a compromise and adjust their work, career and property to spend their time with their families and children,

3. increase of "reflexivity", namely the tendency to think over what is important and how can one's professional life can be shaped. Thanks to the fact that employees have the opportunity to cooperate in diversified teams with people from different cultures and societies, it is expected that they will think more over what is important in life, what career pathway they should choose and at the same time have more courage and energy to undertake the change [Gratton 2011, p. 249].

The Industry $4.0^{1}$ idea where a person (employee) plays a key role, is increasingly discussed in the context of the necessity to deal with disappearing professions on one hand but above all educating within new competences created by technological progress on the other [World Economic... 2016, p. 18].

Different expectations, values and behaviour of new generations will force organizations to know them thoroughly and accept them. This is all done so that new generations can be effectively managed. What is more, the differences between generations do not result just from the fact of belonging to a given group, but are also affected by other influences such as national culture. The growing significance of the diversity issue, also among practitioners in Poland, is proved by the fact of the repeated raising of this subject from different point of views during numerous scientific conferences, business seminars and workshops for practitioners.

\section{Definitions and meaning of diversity in literature of the subject}

The term 'diversity' has been used since the end of the 1950s. Initially it was used in the context of antidiscrimination law created mainly in the United States and Western Europe, protecting the interests and caring for the equal treatment of employees, above all women and ethnic minorities. At the very beginning, there appeared notes on the equality of genders in 1957 along with the establishment of the European Economic Community. In Article 119 of the Treaty of Rome, the member states obliged themselves to introduce and apply the principle of equal pay for male and female workers for equal work [Traktat Rzymski].
The principle of equal treatment of women and men in employment was developed and clarified in further directives and then developed in the legislation of individual states. In Poland, European Directives had been introduced even before Poland accessed the European Union as a part of the amendments to the Labour Code. Article 94 of the Labour Code defines the employer's obligation regarding prevention from discrimination in employment, in particular due to gender, age, disability, race, religion, nationality, political opinions, trade union membership, ethnic origin, religion, sexual orientation, as well as employment for a definite or indefinite period of time or in full or part time employment ${ }^{2}$ [Kodeks pracy].

Diversity in the context of corporate social responsibility (CSR) refers to the diversity of employed persons according to gender, race, nationality and ethnic origin, religion, denomination, no denomination, world view, degree of disability, health condition, age, psychosexual orientation, sexual identity as well as family status, lifestyle and other possible grounds for discrimination ${ }^{3}$. Diversity of employees according to the same source is understood as "any possible, visible and invisible, inborn and acquired, aspects in respect of which people are different and similar to one another, i.e. gender, age, race, ethnic origin, (dis) ability, sexual orientation, religion, domicile, language, marital status, education, professional experience, lifestyle" [Rawłuszko 2007, p. 28].

The concept of business social responsibility regarding employees employed with the organization in the context of diversity is demonstrated by sensitivity to the needs of different employees and through the undertaking of actions in the field of human resources management, i.e.:

- recruitment and selection;

- professional and social adaptation;

- system of training;

- motivating of employees;

- employee assessment;

- horizontal and vertical promotion;

- formation of teams;

which are often a part of company ethical programs [Kwiatek 2014, p. 157]. These actions translate directly into the manner of how the organization is perceived by its external surrounding. According to the research conducted by the Reputation Institute, as much as $60 \%$ of decisions on the purchase, investments or work undertaking is based on how the company is perceived and not on the products or services they sell [Buczkowski i in. 2016, p. 42].

\footnotetext{
${ }^{1}$ Industry 4.0 - The Fourth Industrial Revolution connecting production methods with the hi-tech IT and communication technology. Learn more on: http://www.plattform40.de/I40/Navigation/EN/Industrie40/WhatIsIndustrie40/what-is-industrie40.html, 30/07/2017.

${ }^{2} \mathrm{http} / /$ www.regiopraca.pl/portal/prawo/ustawy/kodeks-pracy-dzial-iv-obowiazki-pracodawcy-i-pracownika-79, 16.07.2017.

${ }^{3} \mathrm{http} / / /$ odpowiedzialnybiznes.pl/hasla-encyklopedii/roznorodnosc/, 03.04.2017.
} 
Diversity of employees is reflected in single features or groups of features [Chatman 2010, p. 448, in: Gajdzik 2015, p. 110]. Diversity is a consequence of such relations where an individual is different only when compared to another individual [Austin, 1997, s. 347, in: Gajdzik 2015, p. 110]. Q.M. Roberson [2004] mentions the notion of social inclusion understood as the degree in which employees have access to information and resources, are included into team work and have the possibility to influence the decision-making process.

\section{Diversity management - arrangement of terminology}

Diversity management, considered to be the highest level of human resources management [WziątekStaśko 2012, p. 21], is a relatively new approach in human resources management, first mentioned in the 1990s. It is based on the belief that differences, heterogeneity and diversity may be managed and, moreover, it is a source of advantages for the organization. Diversity management is a kind of precisely designed in an organization's action plan, a peculiar novel "action practice" [Wziątek-Staśko 2012].

Diversity management in organization is most frequently associated with human resources management [Wziątek-Staśko 2012; Sweeney, McFarlin 1992; Roberson 2004; Komisja Europejska 2005]. Each employee is a unique combination of features that may be depicted in three dimensions of diversity:

1. Original identity (race, nationality, ethnic group, gender, age, sexual orientation, (dis)ability)

2. Secondary identity (level of education, domi-cile, family status etc.)

3. Organizational identity (length of work service, work position, sector etc.) [Raport Firma... 2009, p. 8].

The above-mentioned dimensions are also defined in literature as observable (i.e. gender, age, ethnic origin) and non-observable (professional experience, length of service in the organization, life attitudes) [Wziątek-Staśko 2012]. Other researchers used similar taxonomy by labelling the above dimensions as visible and invisible, controllable and uncontrollable, or predictable and unpredictable [Wziątek-Staśko 2012].

The subject literature provides a range of diversity management definitions (Table 1 and Table 2). The definitions presented below are grouped according to the criterion of scientific definition (Table 1) and institutional definitions, namely those elaborated by research, official and state institutions.
Table 2 below presents the notions used in numerous research reports, governmental documents prepared by institutions and business units.

While analysing the selected definitions of diversity management, one may find that diversity management is above all the deliberate use of employees' diverse features to increase the advantages for the organization and the employees themselves (which is especially raised in scientific definitions). Diversity management is also associated with the corporate social responsibility or purely ethical issues such as preventing any type of discrimination which can be found mainly in institutional definitions.

\subsection{Advantages of employee diversity}

The authors of the definitions quoted above emphasise, above all, the advantages resulting from the use of diversity potential [Robbins 2001; Armstrong 2000; Wziątek-Staśko 2012; Strzelczak 2016], namely the potential of diverse experiences, predispositions, knowledge, skills and sensitivity [Durska 2009]. Diversity in the work place is one of the organization's key resources that contributes to its development and the achievement of business goals. The staff diversity (all possible aspects that differ and make people similar to one another) is one of the key organizational resources which, in certain conditions, may become a source of business advantages [Kirton, Green 2005].

Skillful diversity management, i.e. the transformation of the diversity potential into reality [International Society...], is conducive to the employees' increased involvement and the creation of more productive surroundings [Armstrong 2000, p. 690]. It may also be the source of business advantages [Kirton, Green 2005] and assist in achieving of organizational goals [Schermerhorn 2008, p. 49]. Interestingly, the authors do not demonstrate business advantages for the organizations employing diverse employees only. Working in diverse teams creates development opportunities for the employees themselves and makes them use their potential in full [Armstrong 2000; Kupczyk 2009; Schermerhorn 2008].

\subsection{Creating professional environment conducive to diversity}

Diversity management in an organization according to some authors (e.g. [Armstrong 2000; Brdulak 2009; Wziątek-Staśko 2012; Raport Firma... 2009]), is creating an awareness of the existing differences, perceiving them, accepting and appreciating them as a develop-mental potential for both the company and its employees. 
Table 1. Review of selected scientific definitions of diversity management

\begin{tabular}{|c|c|}
\hline Author & Definition of diversity management \\
\hline $\begin{array}{l}\text { Armstrong M., } \\
2000\end{array}$ & $\begin{array}{l}\text { Diversity management is to lead all employees to use their potential to the maximum and increase their } \\
\text { involvement in the company's affairs. This means the appreciation of diversity, namely the differences among } \\
\text { people and various features they use in their work, and which may lead to the creation of a more productive } \\
\text { surrounding. }\end{array}$ \\
\hline Brdulak H., 2009 & $\begin{array}{l}\text { Diversity management as a business model. Diversity is a process of directing (including communication) } \\
\text { consisting in active, aware and future-oriented development of the organization based on values. Acceptance } \\
\text { of existing differences and treating them as the company's potential for development are its basis. }\end{array}$ \\
\hline $\begin{array}{l}\text { Cox T.H., } \\
\text { Blake S., } 1991\end{array}$ & $\begin{array}{l}\text { Diversity management refers to the range of issues associated with management and activities regarding } \\
\text { employment and the effective use of employees coming from different cultural environments. }\end{array}$ \\
\hline Durska M., 2009 & $\begin{array}{l}\text { Diversity management means therefore the use of various experiences, varied knowledge, skills, predispositions } \\
\text { and sensitivity (purely professional but also cultural) in the whole organization or company. }\end{array}$ \\
\hline Fazlagić J., 2014 & $\begin{array}{l}\text { Diversity management may be defined as a strategy the purpose of which is to create and maintain a working } \\
\text { environment that is friendly to the employees through respect and sensitivity to their diversity resulting from } \\
\text { demographic, social and other features. In an organizational structure, it is usually the HR Management Department } \\
\text { who is responsible for the implementation of the diversity management strategy (program). }\end{array}$ \\
\hline $\begin{array}{l}\text { Stankiewicz K., } \\
\text { Ziemiański P., } \\
2012\end{array}$ & $\begin{array}{l}\text { This concept is based on the assumption that a conscious action aimed at the use of diversity of the employees will } \\
\text { allow to create such a working environment where all employees' talents are involved in order the organization's } \\
\text { goals could be achieved. }\end{array}$ \\
\hline $\begin{array}{l}\text { Gryszko M., } \\
\text { Lisowska E., } \\
2009\end{array}$ & $\begin{array}{l}\text { This HR management strategy is based on the belief that the staff diversity (all possible aspects that differ and } \\
\text { make people similar to one another) is one of the key organizational resources which, in certain conditions, may } \\
\text { become a source of business advantages. }\end{array}$ \\
\hline $\begin{array}{l}\text { Kupczyk T., } \\
2009\end{array}$ & $\begin{array}{l}\text { Diversity management is equivalent to creating some conditions to the employees that allow them to use their } \\
\text { possibilities in full and their own development understood from the individual's point of view. This way } \\
\text { of management may therefore contribute to the achieving of advantages by individuals, organizations } \\
\text { or companies. Within a wider context, the whole of society will be the beneficiary of diversity due to the fact that } \\
\text { the key for this style of thinking is the notion of change - therefore, at a more general level, it is about changes that } \\
\text { take place in demography or culture, while at a detailed level - social (also consumer's) expectations, and their } \\
\text { expectations from work. }\end{array}$ \\
\hline $\begin{array}{l}\text { Robbins S.P., } \\
2001\end{array}$ & $\begin{array}{l}\text { Diversity management is based on the belief that the heterogeneity diversity may be managed for the benefit } \\
\text { of others. }\end{array}$ \\
\hline $\begin{array}{l}\text { Roberson Q.M., } \\
2004\end{array}$ & $\begin{array}{l}\text { Diversity management is a group of activities in the area of human resources management in order to increase } \\
\text { and maintain the human resources heterogeneity, increasing advantages due to diversity and limiting problems. }\end{array}$ \\
\hline $\begin{array}{l}\text { Schermerhorn } \\
\text { J.R., } 2008\end{array}$ & $\begin{array}{l}\text { Diversity management as a process of the versatile shaping of the working environment that makes every } \\
\text { employee use their potential for achieving organizational goals. }\end{array}$ \\
\hline $\begin{array}{l}\text { Strzelczak M., } \\
2016\end{array}$ & $\begin{array}{l}\text { DM refers both to perceiving differences among employees and being aware development of the strategies, policies } \\
\text { and programs that form a climate for respecting and using of these differences for the benefit of achieving the } \\
\text { organizational goals [as in Urbaniak 2014]. }\end{array}$ \\
\hline $\begin{array}{l}\text { Rogozińska- } \\
\text { Pawełczyk A., } \\
2016\end{array}$ & $\begin{array}{l}\text { Diversity management is an approach to human resources management in an organization the purpose of which } \\
\text { is to create and maintain a friendly working environment for employees through perceiving individualism and } \\
\text { diversity in them resulting from features such as gender, age, race, ethnic origin, disability and others, } \\
\text { of a social and demographic nature. }\end{array}$ \\
\hline $\begin{array}{l}\text { Walczak W., } \\
2011\end{array}$ & $\begin{array}{l}\text { Diversity management is an approach to HRM in an organization the purpose of which is to create and maintain } \\
\text { a friendly working environment for employees through perceiving individualism and diversity in them resulting } \\
\text { from features such as gender, age, race, ethnic origin, disability and others, of a social and demographic nature. } \\
\text { Diversity management may be treated as an advanced concept of knowledge and talent management in an } \\
\text { organization, putting a special emphasis on the equalisation of opportunities, prevention from social exclusion, } \\
\text { integration of employees and the ethnic and moral dimension of business conduct as well as social } \\
\text { responsibility. }\end{array}$ \\
\hline $\begin{array}{l}\text { Wziątek- } \\
\text { Staśko A., } \\
2012\end{array}$ & $\begin{array}{l}\text { Diversity management pertains to, above all, the building of awareness and the acceptance of social and } \\
\text { demographic differences in an organization as well as undertaking activities allowing to use these differences in } \\
\text { a manner that is beneficial to the organization. }\end{array}$ \\
\hline
\end{tabular}

Source: own elaboration based on literature review [Armstrong 2000; Brdulak 2009; Cox, Blake 1991; Durska 2009; Fazlagić 2014; Stankiewicz, Ziemiański 2012; Gryszko, Lisowska 2009; Kupczyk 2009; Robbins 2001; Roberson 2004; 2008; Strzelczak 2016; Rogozińska-Pawełczyk 2016; Walczak 2011; Wziątek-Staśko 2012]. 
Table 2. Review of selected institutional definitions of diversity management

\begin{tabular}{|c|c|}
\hline Source & Definition of diversity management \\
\hline $\begin{array}{l}{[\text { Company=Diversity }} \\
\text { Report }]\end{array}$ & $\begin{array}{l}\text { Diversity management means seeing differences among people in an organization (and outside it) and the } \\
\text { conscious development of strategies, policies and programmes, that create a climate for respecting and } \\
\text { using these differences in a manner that is beneficial to the organization. The purpose of diversity } \\
\text { management is to create such a working environment where each employed person feels respected and } \\
\text { appreciated and where he or she may take advantage of their potential which contributes to the organization's } \\
\text { success. }\end{array}$ \\
\hline $\begin{array}{l}{[\text { Responsible }} \\
\text { Business Forum }]\end{array}$ & $\begin{array}{l}\text { Diversity management are all the organization's activities that aim at the consideration and the optimum } \\
\text { use of diversity at the place of work. }\end{array}$ \\
\hline $\begin{array}{l}{[\text { International }} \\
\text { Society for Diversity } \\
\text { Management }]\end{array}$ & $\begin{array}{l}\text { Diversity Management is thought to be a more universal management discipline than most of the others. It is } \\
\text { not only human resources management. The purpose of diversity management is to use the positive } \\
\text { potential of diversity and transform the same into reality. The awareness of diversity and the ability to manage } \\
\text { the same are necessary conditions of success. }\end{array}$ \\
\hline $\begin{array}{l}\text { [Guidebook for } \\
\text { managing diversity }]\end{array}$ & $\begin{array}{l}\text { The HR management strategy which assumes that diversity in the place of work is one of the organization's } \\
\text { key resources that contributes to its development and achieving business goals. }\end{array}$ \\
\hline $\begin{array}{l}\text { [Equality. } \\
\text { infoFoundation] }\end{array}$ & $\begin{array}{l}\text { Diversity management is the totality of strategies, plans, processes and procedures as well as measurement } \\
\text { tools to be in force in an organization, associated with the diversity issue. Their role is usually twofold: } \\
\text { internal i.e. the full use of the potential of the persons employed with the organization, and external i.e. } \\
\text { adjusting its profile to the needs of diverse target groups. }\end{array}$ \\
\hline $\begin{array}{l}{[\text { European }} \\
\text { Commission] }\end{array}$ & $\begin{array}{l}\text { Human resources management in considering the individual differences, respects otherness in the place of work } \\
\text { (excluding types of behaviour which are unacceptable in the organization). }\end{array}$ \\
\hline $\begin{array}{l}\text { [Constitution of the } \\
\text { Republic of Poland }]\end{array}$ & $\begin{array}{l}\text { Article } 32,1 \text {. All persons are equal before the law. All persons shall have the right to equal treatment by the } \\
\text { public authorities. } 2 \text {. No one shall be discriminated against in political, social or economic life for any reason } \\
\text { whatsoever. Article } 33,1 \text {. Men and women in the Republic of Poland shall have equal rights in family, political, } \\
\text { social and economic life. } 2 \text {. Men and women shall have equal rights, in particular, regarding education, } \\
\text { employment and promotion, and shall have the right to equal compensation for work of similar value, to } \\
\text { social security, to hold office, and to receive public honours and decorations. }\end{array}$ \\
\hline [Labour Code] & $\begin{array}{l}\text { Chapter 2a: Equal treatment in employment, Article } 18 \text { : Employees should be treated equally in relation to } \\
\text { establishing and terminating an employment relationship, employment conditions, promotion conditions, } \\
\text { as well as access to training in order to improve professional qualifications, in particular regardless of } \\
\text { sex, age, disability, race, religion, nationality, political beliefs, trade union membership, ethnic origin, } \\
\text { creed, sexual orientation, as well as regardless of employment for a definite or indefinite period of time or } \\
\text { full time or part time employment. Equal treatment in employment means that there must be no } \\
\text { discrimination whatsoever, directly or indirectly, on the grounds referred to in } \S 1 \text {. }\end{array}$ \\
\hline
\end{tabular}

Source: own elaboration base on literature review based on sources mentioned in the Table 2.

This is related to the necessity of creating such a working environment by organizations which will be conducive to diverse individuals and teams [Fazlagić 2014; Sweeney, McFarlin 1992]. This is also creating such working conditions which will make the employees to use their possibilities in full and their own development understood from the individual point of view [Kupczyk 2009]. Adiversity-friendly environment is such an environment which can see individuality and diversity resulting from features such as gender, age, race, ethnic origin, disability and others, of a social or demographic nature [Sweeney, McFarlin 1992].

\subsection{Management through values}

This is very close to the management through values emphasised, among others, by Brdulak [2009] and Fazlagić [2014], who show respect and sensitivity to the diversity of employees resulting from demographic, social and other features and the necessity to create a working environment based on these values. According to Company=Diversity Report, the values that support the meaning of diversity is respect to all people regardless of differences, constant search for new solutions, openness to various ideas, active responding to ongoing needs, and supporting innovations [Raport Firma ... 2009]. Following on the same report, the purpose of diversity management is to create such a working environment where each employed person feels respected and appreciated and where he or she may take advantage of their potential which contributes to the organization's success.

\subsection{Diversity vs CSR}

Appreciation and respect for diversity of employees is one of the basic values of organizations aimed at sustainable human resources management [Pocztowski 
2016] and an element of corporate social responsibility [Zarzadzanie różnorodnością... 2013]. The importance of corporate social responsibility (CSR) is also growing in importance as a factor conditioning the image of the employer. Walczak [2011] and Gerszta [2011] draw attention to the ethical and moral dimension of business conduct and its social responsibility. In institutional definitions, the antidiscrimination and equality-oriented approach prevails. The Labour Code is concentrated on the equal treatment of employees [Kodeks pracy...]. The Constitution emphasises the equal rights of men and women in family, political, social and economic life. All persons are equal in law and no-one may be discriminated for any reason whatsoever [Konstytucja Rzeczypospolitej...]. Therefore, organizations, as a part of their HR policies and ethic codes, undertake activities aimed at the promotion of equal treatment, equal opportunities and prevention from discrimination in the work place.

\subsection{Diversity vs human resources management}

Diversity became an issue significant from the organization's functioning point of view along with the beginning of perceiving the human factor in an organization as a potential [Jamka 2011]. Consequently, diversity management, in many researchers' opinion, is closely related to human resources management [Wziątek-Staśko 2012; Sweeney, McFarlin 1992; Roberson 2004; Komisja Europejska 2005]. These activities serve to expand and maintain the human resources' heterogeneity, increasing the advantages due to diversity and the limiting problems [Roberson 2004]. Diversity management involve all the organisation's activities that aim at the consideration and the optimum use of diversity at the place of work [Raport Firma... 2009]. This is an approach to human resources management in an organization the purpose of which is to create and maintain a friendly working environment for employees through perceiving individualism and diversity in them resulting from features such as gender, age, race, ethnic origin, disability and others, of a social and demographic nature [Sweeney, McFarlin 1992]. Moreover, diversity management is deemed even as the highest contemporary stage of human capital management [Wziątek-Staśko 2012].

Some researchers and practitioners define wider diversity management claiming that it is a more universal discipline of management than most of the other ones, not only human resources management. Its purpose is to use the positive potential of diversity and transform the same into reality. Awareness of diversity and the ability to manage the same are necessary conditions of success [International Society...]. Diversity management is also a process of directing and communication [Brdulak 2009], regarding many issues related to management including knowledge and talent management in an organization [Walczak 2011].

The literature on the subject presents the management of cultural diversity as a "double-edged sword" [Miliken, Martins 1996, p. 403], due to its positive and negative consequences. From the MNC's perspective, cultural differences make management methods ineffective in certain cultural settings of branches [Rozkwitalska 2016, p. 23], and according to T. Oleksyn, cultural diversity introduces additional difficulties in HRM [Oleksyn 2014, p. 496].

The negative consequences of cultural diversity include: increasing uncertainty related to the increase of diversity, difficulties in agreeing actions and meanings, as well as difficulties and errors in communication that make agreement difficult [Glinka, Kostera, Brzozowska 2012; Rozkwitalska 2011]. One can point to barriers in managing a diverse team that result from individual characteristics (e.g. lack of openness to experience, low cognitive motivation, low intelligence and cultural flexibility, neuroticism, lack of knowledge of a foreign language, ethnocentrism), group interactions (including lack of mutual trust, lack of cohesion of the group) and organization (e.g. institutional ethnocentrism, lack of a systematic approach to sharing intercultural experiences within the organization, lack of care for the image of a company responsible in the field of cultural diversity) [Przytuła, Krysińska-Kościańska 2017, p. 105].

The analysis of diversity of people employed in the organization should be the starting point for the development of the diversity management plan. This is relatively easy to carry out, thanks to the obligation to maintain employment documentation by employers. The analysis of the employed staff will allow to consider whom the organization needs to recruit and develop in terms of knowledge, experience, competences, age, gender, nationality, etc. This is not about the guarantee to observe the law regarding antidiscrimination regulations, but rather about the ability to use the advantages coming from the diversity and fulfil the assumed business goals. The abovementioned analysis, especially the activities undertaken that serve maintaining the proportions of each of the age groups, may minimise the risks related, for example, to the retirement of a large number of employees and the necessity to introduce new employees. 
It is worth assessing the status of the diversity management policy's implementation, for example, in the Diversity Index survey carried out regularly in Poland (two surveys have been carried out to date) by the Lewiatan Confederation that assesses the following six areas of diversity policy:

1. strategic diversity management;

2. organisational culture;

3. employment structure;

4. recruitment;

5. professional development;

6. remuneration [Diversity Index... 2013].

Following the completed survey, the participants receive individual Diversity Index and feedback information together with recommendations as well as examples of good practices in the field of diversity management, which may be a useful and inspirational starting point to undertake activities within the area of diversity management.

The aforementioned L. Gratton shows five important areas from the HR perspective:

1. authentic and transparent leadership;

2. structure (use of matrix organization or project teams);

3. standards and values;

4. practices and processes (i.e. regarding remuneration);

5. support in acquiring new competences and skills [Gratton 2011].

The meaning of leadership, and more precisely the leaders' preferred behaviour in the management of diverse teams in the light of cultural challenges, is quoted in the GLOBE ${ }^{4}$ Project research.

The quoted perspectives refer to almost every sub-function of the human resources management i.e.:

1. staff planning;

2. staff selection;

3. development and motivation;

4. leaving (exit) of employees [Listwan 2010, p. 34].

Therefore it is worth proposing particular areas and activities that may be considered in the context of personnel function.

At the stage of staff planning, the activities that should be considered include numbers in the managerial or other positions where disproportions exist (these are often technical positions) and determine deadlines for their achievement. Business reports and analysis confirm that the increased ratio of women at the highest positions may significantly contribute to the improvement of results 5 . Some companies openly communicate this, for example, $41 \%$ of women employed at managerial positions in the Mars company in $2016^{6}$. At Vodafone Group ple, $21 \%$ of middle level managers are women. Women are also $44 \%$ of all Vodafone employees [Rozkwitalska 2007, p. 33]. The most important qualities are knowledge, competences, expertise and attitude of the candidates. One cannot be promoted only due to fixed numbers. It is also significant, as emphasised by Klimkiewicz, that the main advantages of diversity management are related to the change of behavior of an organization's members, which causes a gradual change of understanding diversity management as the management of the factors of the employment structure towards the management consisting in taking decisions considering the diversity among employees, their systems of values, aspirations, ex-pectations and potential which is connected therewith [Klimkiewicz 2010].

While planning the employment, it is worth taking a closer look at the age diversity in individual teams. This is important not only in the context of knowledge and skills exchange among the more and the less experienced employees, but also about ensuring balance in individual age categories and minimising any possible risk that a greater number of employees retire around the same time. This would cause a material competence gap, complications connected with the loss of capital such as knowledge, experience and skills as well as the necessity to train a sizeable group of new employees. Introducing new employees is time-consuming and requires thorough preparation and involvement on the part of the organization.

The selection of employees which includes the recruitment, choice and introduction to work, should be started from the development of clear transparent rules of recruitment and selection. All candidates should have access to the same information i.e. a description of the position including the tasks and responsibilities in the given position and the requirements for candidates plus the course of the selection process (stages, participants, dates, methods, etc.). Most organizations, especially international ones, place the said information on their websites (like IKEA ${ }^{7}$, Deloitte ${ }^{8}, \mathrm{PWC}^{9}$, Philipp

\footnotetext{
${ }^{4} \mathrm{http}: / /$ globeproject.com/results/countries/POL?menu=country, 14.07.2017.

${ }_{5}^{5}$ Report: Women matter, 2016, http://www.mckinsey.com/france/our-insights/women-matter-2016/fr-fr and Report: Women in boardroom, 2017, https://www2.deloitte.com/content/dam/Deloitte/ch/Documents/risk/ch-en-women-in-boardroom.pdf.

${ }^{6} \mathrm{http} / / / \mathrm{mars} . c 0 \mathrm{~m} / \mathrm{global} / \mathrm{careers} /$ work-at-mars/enjoy/diversity-inclusion, 30.07.2017.

${ }^{7} \mathrm{http}: / /$ www.ikea.com/ms/pl_PL/this-is-ikea/working-at-the-ikea-group/pracuj-w-ikea.html, http://www.ikea.com/ms/pl_PL/this-is-ikea/working-at-the-ikea-group/faq.html, 30072017.

${ }^{8} \mathrm{https} / / /$ www2.deloitte.com/pl/pl/pages/careers/articles/students/proces-rekrutacji.html, 30.07.2017.

${ }^{9}$ http://kariera.pwc.pl/procesSelekcji.html, 30.07.2017.
} 
Table 3. Managing diversity in chosen sub-functions of HRM

\begin{tabular}{|c|c|c|}
\hline Dimension & $\begin{array}{l}\text { Subfunction } \\
\text { of HRM }\end{array}$ & Examples of activity \\
\hline \multirow{7}{*}{ 舀 } & Planning & Numbers of managerial positions (or others where disproportions occur, like technical positions). \\
\hline & \multirow[t]{2}{*}{ Recruitment } & Consideration of the above during selection, after prior meeting of competence requirements by candidates. \\
\hline & & $\begin{array}{l}\text { Drawing up recruitment announcements promoting teams differentiated according to gender, age, culture, } \\
\text { experience and competences, etc. }\end{array}$ \\
\hline & Development & $\begin{array}{l}\text { Creating of diversity awareness, breaking down stereotypes on diversity, influencing attitudes to diversity, } \\
\text { approach to diversity (especially of the managerial staff). }\end{array}$ \\
\hline & \multirow[t]{3}{*}{ Motivating } & Diverse range of benefits corresponding to the needs of employees. \\
\hline & & $\begin{array}{l}\text { Conducting structured interviews (,stay interview”) with the purpose of the ongoing monitoring of the } \\
\text { employee's level of motivation. }\end{array}$ \\
\hline & & $\begin{array}{l}\text { Promotion of health, work-life balance, flexible employment forms allowing to reconcile professional and } \\
\text { private areas of life. }\end{array}$ \\
\hline \multirow{13}{*}{ 岁 } & \multirow[t]{2}{*}{ Planning } & $\begin{array}{l}\text { Planning of age diversity in teams aimed at supporting the exchange of knowledge and skills, expertise as well } \\
\text { as ensuring a balance in individual age categories plus minimising disproportions. }\end{array}$ \\
\hline & & Development of succession and knowledge transfer plans. \\
\hline & \multirow[t]{3}{*}{ Recruitment } & Considering diversity in terms of age during selection. \\
\hline & & $\begin{array}{l}\text { Drawing up recruitment announcements promoting teams differentiated according to gender, age, culture, } \\
\text { experience and competences, etc. }\end{array}$ \\
\hline & & $\begin{array}{l}\text { Non-indication of age in recruitment announcements and placing announcements in communication channels } \\
\text { reaching age-diversified groups of candidates. }\end{array}$ \\
\hline & \multirow[t]{5}{*}{ Development } & Age management programs (i.e. mentor programs that support knowledge transfer). \\
\hline & & Involvement of older, experienced employees in the induction of new ones in the company. \\
\hline & & Adjusting training methods to the needs of individual groups. \\
\hline & & $\begin{array}{l}\text { Creating of diversity awareness, breaking down stereotypes on diversity, influencing attitudes to diversity, } \\
\text { approach to diversity (especially of the managerial staff). }\end{array}$ \\
\hline & & Conducting regular survey research aimed at the examination of motivation level and employee involvement. \\
\hline & \multirow[t]{3}{*}{ Motivating } & Diverse range of benefits corresponding to the needs of employees X, Y, Z. \\
\hline & & $\begin{array}{l}\text { Conducting structured interviews (,stay interview”) with the purpose of the ongoing monitoring of the } \\
\text { employee's level of motivation. }\end{array}$ \\
\hline & & $\begin{array}{l}\text { Promotion of health, work and life balance, flexible (time, place) employment forms allowing to reconcile } \\
\text { professional and private areas of life and interests. }\end{array}$ \\
\hline \multirow{8}{*}{ 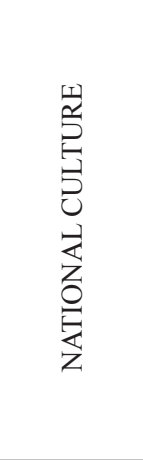 } & Planning & $\begin{array}{l}\text { Planning of cultural diversity in teams aimed at supporting the exchange of experiences and attitude points } \\
\text { of view resulting from life/work in other cultural circles. }\end{array}$ \\
\hline & \multirow[t]{2}{*}{ Recruitment } & Considering cultural diversity during selection. \\
\hline & & $\begin{array}{l}\text { Drawing up recruitment announcements promoting teams differentiated. according to gender, age, culture, } \\
\text { experience and competences, etc. }\end{array}$ \\
\hline & \multirow[t]{4}{*}{ Development } & Intercultural training. \\
\hline & & Foreign transfers as an element of a professional carrier. \\
\hline & & Creating intercultural teams. \\
\hline & & $\begin{array}{l}\text { Diversity awareness, breaking down stereotypes on diversity, influencing attitudes to diversity, approach } \\
\text { to diversity (especially of the managerial staff). }\end{array}$ \\
\hline & Motivating & Diverse range of benefits corresponding to the needs and expectations of representatives of individual cultures. \\
\hline \multirow{8}{*}{ 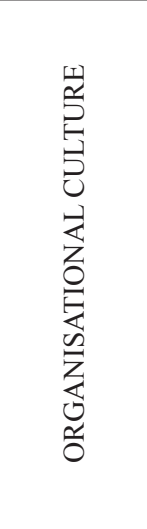 } & Planning & $\begin{array}{l}\text { Planning of activities regarding shaping of organizational culture, communication of these activities } \\
\text { and involvement of employees in its creation. }\end{array}$ \\
\hline & \multirow[t]{2}{*}{ Recruitment } & Promotion of company values during recruitment of candidates. \\
\hline & & Verification during selection whether the candidates share similar values. \\
\hline & \multirow[t]{2}{*}{ Development } & Offering team work if it is an element of organizational culture. \\
\hline & & $\begin{array}{l}\text { Creating of diversity awareness, breaking down stereotypes on diversity, influencing attitudes to diversity, } \\
\text { approach to diversity (especially of the managerial staff). }\end{array}$ \\
\hline & Motivating & $\begin{array}{l}\text { Involving employees in reporting of their ideas improving the cooperation and climate in organization, } \\
\text { communication promoting health / healthy lifestyle. }\end{array}$ \\
\hline & \multirow[t]{2}{*}{$\begin{array}{l}\text { Leaving } \\
\text { and dismissals }\end{array}$} & $\begin{array}{l}\text { Culture of leaving/exit - drawing up the rules regarding the way of terminating contracts by employees } \\
\text { and employers, the way of conduct during notice period, communication of leaving in the organisation. }\end{array}$ \\
\hline & & $\begin{array}{l}\text { Collecting and responding to the feedback information from the employees leaving the organization on the } \\
\text { reasons of their leaving the company (so-called „exit interviews”). }\end{array}$ \\
\hline
\end{tabular}

Source: own elaboration based on elements of HR management [Listwan 2010]. 
Morris $^{10}$, Mars $\left.^{11}\right)$. The standardisation of the recruitment process ensures the equal treatment of both male and female candidates. For that purpose, the questions and assessment criteria of candidates should be worked out prior to the interviews being commenced. The persons starting work as recruiters should be trained in how to conduct interviews and receive clear guidelines on discriminatory question that are prohibited in the recruitment process.

Bearing in mind the recruitment of diverse employees to the organization, it is worth preparing recruitment announcements that promote teams diversified in terms of gender, age, culture, experience and competences as well as truly reflecting the reality of the given company at the same time. In this context, it is also important not to specify the preferred age or gender in the recruitment announcements or other wordings that are illegal or imply discrimination. It is also important to ensure placing announcements in communication channels that will reach diverse (for example in terms of age) groups of candidates. In the selection process itself, one should ensure the participation of a minimum two persons, thanks to which the risk of personal prejudices or discrimination will be minimised.

The said rules should be communicated within the organization and presented to the external candidates invited to participate in the selection process. The internal candidates should be informed and actively encouraged to apply for vacant positions in the organization and their present superiors cannot prevent them from changing their position or promotion even if it is a kind of impediment to the current functioning of the department in a short term. Communicating vacancies within the organization may be the impulse for those employees who have not taken part in internal selection before, regardless of the reason, and have not thought about changing their position from their own development point of view.

Within diversity management, a properly conducted recruitment and selection decide the level of diversity of the employment structure in the company. It is relevant to ensure the quality of recruitment communications which may help in employing candidates from desired environments or with desired competences and expertise, and therefore enrich the diversity of staff in an organization.

While motivating the employees, the level of their motivation and involvement needs to be regularly monitored. Regularly, i.e. once a year, there needs to be conducted survey research followed by a process of communicating both the results and scheduled activities as well as the employee involvement to agree corrective and improving activities. Additionally, the culture of feedback information in the organization should be promoted, structured interviews with employees should be conducted in order that their needs could be known on a regular basis and the motivators to be applied could be understood. Diverse teams mean diverse expectations from motivation. What is crucial in motivation is the familiarity with both the employees and the differences in their needs and expectations, as well as what kind of motivators may effectively or ineffectively affect women, men, representatives of generations, well-educated people, people of different ages, from different cultures, occupying different positions and being on different levels of their career development. This is a very complex issue as the work team is a group of many individuals having individual views, aspirations and aims, which in turn generates the necessity of the individualisation of the motivational tools [WziątekStaśko 2012].

The guarantee of equal opportunities of promotion and professional career development is an important element of diversity management policy. While designing the career path and employee's development, one should foresee the access to development programs for all employees regardless of their gender, age, national culture, etc. Full access to development means means also the opportunity for an employee to nominate $\mathrm{him} /$ herself to development programs or apply for vacancies within internal recruitment. It seems obvious that the procedures of self-nomination, selection and final acceptance to the program need to be clear and understandable, just as in the case of recruitment.

The awareness of diversity should be aimed at the employees, the respect for diversity should be shaped, as well as the advantages and opportunities should be indicated to them. Appreciating the diversity of various groups of employees, managers and candidates, many companies address special development programs to them, for example Equal at Work - diversity initiatives: Women in Technology, IBM - women friendly company, Men \& Women in Technology Together, Academic Partnership - Disability ${ }^{12}$, Carrier in Deloitte ${ }^{13}$, Deloitte SheXO Club ${ }^{14}$. International organizations hold intercultural training, thematic

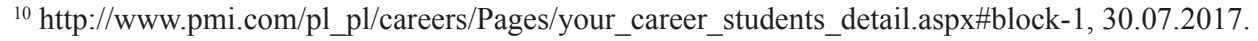

${ }^{11} \mathrm{https}: / /$ www.marskariera.pl/poradnik-rekrutacyjny, 30.07.2017.

$12 \mathrm{http}: / / \mathrm{www}-05 . \mathrm{ibm} . \mathrm{com} / \mathrm{pl} / \mathrm{responsibility/,} \mathrm{30.07.2017.}$

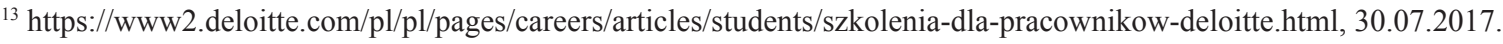

${ }^{14} \mathrm{https}$ //www2.deloitte.com/pl/pl/pages/kobiety-w-biznesie/solutions/Klub-SheXO.html, 30.07.2017.
} 
meetings devoted to different cultures, and there are created intercultural teams or organized transfers among countries and locations, as part of a professional career that gives the possibility to take further higher positions in the company hierarchy.

Special attention should be paid to those social groups that may be burdened with negative stereotypes. Solutions may include training and discussions on stereotypes and ways of breaking them down. But the key issue here are the attitudes to diversity of the managerial staff themselves and their ability to influence the attitudes of employees. While developing the diversity culture in an organization, one should plan training courses covering the following issues:

1. existing legislation and its practical application

2. roles and responsibilities of persons in charge of diversity management

3. methodology of conduct in cases of discrimination at work

4. strengths and weaknesses resulting from diversity [Wziątek-Staśko 2012].

Development programs should correspond to the business needs of the organization and consider the developmental needs of the employees as well as building a balance between professional and private life. "Our colleagues are not robots but real people who, like us, experience their problems, enter new life roles, feel joy and worries" declares Mars ${ }^{15}$ on their company website. Employees appreciate if the organization understands their personal needs. On the other hand, lack of balance between work and life is a source of many negative consequences for employees, their families and society, and also to the organization, including increased turnover, absence, lowered involvement, stress and lack of concentration at work [Borkowska 2010]. Regarding different needs, especially of employees of different age and of different gander, and in order to ensure balance between work and life, the organizations offer flexible forms of employment, for instance part-time work, individual working hours, flexible working time, telework, weekend work, the possibility to leave work to deal with own private matters and work those hours off on another day, as well as other options [Sznajder 2013, p. 45].

The system of periodical assessment corresponding to the assumptions of diversity management policy should include the assessment criteria without stereotyping or discriminating signs such as readiness to work overtime or on 3-4 rota basis. This criterion may cause the less advantageous assessment of employees who have no possibility to work nonstandard working hours.
While assessing employees, the criterion of evaluating behaviour against diversity needs to be considered. For example, an assessment sheet may include an item on tolerance, sensitivity, openness, respect for diversity.

Practices in the field of dismissals and leaving of employees are an important area in the context of diversity management. The elaboration of rules regarding the course of termination of employment contracts by employees and by the employer, the way of conduct during the notice period, the communicating of leaving the organization, all create the desired "culture of leaving/exit" from the organization on one hand, and on the other allow to act according to the law and prevent possible discrimination. Familiarity with the rules that are followed during leaving may also strengthen the employees' feeling of comfort and safety at work. Many employers get the feedback information from the employees who leave the organization regarding the reasons for leaving (socalled "exit interviews") and implement adjustments to their procedures and practices. More appropriate seems to be ongoing monitoring of the level of involvement and satisfaction from work, as well as interviews with employees that are of a structure similar to "exit interviews" during employment. Thus there is a higher probability that the employee will not leave the company.

\section{Conclusion}

To sum up there is no one, common definition of diversity and diversity management. Usually, diversity management is considered from three perspectives: the purely legal perspective (protection of interests and rights of minorities, equality), the business perspective (from the point of view of advantages possible to obtain thanks to diverse staff) and the ethical perspective. Regardless of the difficulties in the unequivocal definition of the diversity management concept, we observe the growing interest in this issue resulting from the ongoing demographic, social and technological transformations.

Diversity will remain a challenge to be faced by organizations functioning in diverse societies. This article presents examples of activities that may be helpful in diversity management. Diverse teams require diverse management styles based on familiarity with the needs, values and expectations of the team. Managerial staff, having diagnosed the differences in the needs and expectations of individual employees, will have to adjust the management style

\footnotetext{
${ }^{15} \mathrm{https} / / /$ www.marskariera.pl/mars-work-life-balance, 30.07.2017.
} 
to the team. Therefore, the key issue is to train the managerial staff within the identification of the needs of diverse teams and their ability to manage them as well as to shape organizational culture promoting diversity.

\section{Bibliography}

Armstrong M., 2000, Zarządzanie zasobami ludzkimi, Dom Wydawniczy ABC, Kraków.

Aminu Mamman A., Kamoche K., Bakuwa R., 2012, Diversity, organizational commitment and organizational citizenship behavior: an organizing framework, Human Resource Management Review, 22.

Borkowska S., 2010, Równowaga między praca a życiem pozazawodowym, Acta Universitatis Lodziensis. Folia oeconomica, no 240.

Brdulak H., 2009, Zarządzanie różnorodnościa jako model biznesowy, „Kobieta i Biznes” nr 1-4.

Bukowska U., 2014, Zarządzanie różnorodnościa pracowników w świetle społecznej odpowiedzialności, [in:] Depta A. (ed.), Wspótczesne problemy zarządzania a spoteczna odpowiedzialność, Monografie Politechniki Łódzkiej, Łódź.

Buczkowski B., Dorożyński T., Kuna-Marszałek A., Serwach T., Wieloch J., 2016, Społeczna odpowiedzialność biznesu. Studia przypadków firm międzynarodowych, Wydawnictwo Uniwersytetu Łódzkiego, Łódź.

Cox T.H., Blake S., 1991, Managing Cultural Diversity: implications for organizational competitiveness, Academy of Management Executive, vol. 5, no 3.

Deloitte Global Human Capital Trends. The new organization: different by design, 2016, https://www2.deloitte.com/content/dam/Deloitte/global/Documents/HumanCapital/gx-dupglobal-human-capital-trends-2016.pdf, 15.07.2017.

Deloitte Millennial Survey, Mind the gaps, 2015, https://www2. deloitte.com/content/dam/Deloitte/global/Documents/ About-Deloitte/gx-wef-2015-millennial-survey-executivesummary.pdf, 15.07.2017.

Diversity Index. Przewodnik po zarządzaniu różnorodnościa, 2013, Konfederacja Lewiatan, Warszawa, http://www.diversityindex.pl/Content/uploaded/files/Przewodnik/pdf.

Donnelly R., Tension and Challenges in the management of diversity and inclusion in IT services multinationals in India, Human Resources Management, March-April 2015, no 2.

Durska M., 2009, Zarządzanie różnorodnością: kluczowe pojęcia, Kobieta i Biznes, nr 1-4.

Fazlagić J., 2014, Zarządzanie różnorodnościa a zarządzanie wie$d z q$, ,E-mentor”, no 1(53).

Gajdzik B., 2015, Zarządzanie różnorodnościa zasobów ludzkich w przedsiębiorstwie hutniczym, Zeszyty Naukowe WSH, Zarządzanie.

Gajek K., 2014, Zarzadzanie różnorodnościa w polskich organizacjach, Prace Naukowe Uniwersytetu Ekonomicznego we Wrocławiu, nr 350.

Gerszta M., 2011, Dziat personalny - kluczowy sojusznik w realizacji strategii CSR, Harward Business Review, no 85.

Glinka B., Kostera M., Brzozowska A., 2012, Różnorodność kulturowa wspótczesnych organizacji, [in:] Kostera M., Glinka B. (eds.), Nowe kierunki w organizacji i zarządzaniu, Wolters Kluwer Polska, Warszawa.

Gratton L., Workplace 2025. What will it look like?, 2011, Organizational Dynamics, 40:4.

Gryszko M., Lisowska E., 2009, Zarządzanie różnorodnościa w Polsce, Forum Odpowiedzialnego Biznesu, Warszawa.
International Society for Diversity Management, www.idm-diversity.org, 16.07.2017.

Jamka B., 2011, Czynnik ludzki we wspótczesnym przedsiębiorstwie: zasób czy kapitat? Od zarządzania kompetencjami do zarzadzania różnorodnościa, Wydawnictwo Wolters Kluwer, Warszawa.

Kirton G., Green A.M., 2005, The Dynamics of Managing Diversity: A Critical Approach, Elsevier Butterworth-Heinemann.

Klimkiewicz K., 2010, Zarządzanie różnorodnościa jako element prospołecznej polityki przedsiębiorstwa, Współczesne Zarządzanie, $\mathrm{nr} 2$.

Kodeks pracy, Ustawa z dnia 26 czerwca 1974 r., DzU nr 24, pos. 141.

Komisja Europejska, 2005, Różnorodność w firmach - dobre praktyki w miejscu pracy. Podstawowe prawa i przeciwdziatanie dyskryminacji, Bruksela.

Konstytucja Rzeczypospolitej Polskiej, DzU 1997 nr 78.

Kopeć J., 2014, Kształtowanie rozwiazań ułatwiajacych zarzadzanie różnorodnościa pracowników, Prace Naukowe Uniwersytetu Ekonomicznego we Wrocławiu, nr 349.

Kupczyk T., 2009, Kobiety w zarządzaniu i czynniki ich sukcesów, Wyższa Szkoła Handlowa, Wrocław.

Kwiatek A., 2014, Spoleczna odpowiedzialność a różnorodność w organizacjach, Politechnika Częstochowska.

Leks-Bujak E., 2014, Zarządzanie różnorodnościa w organizacji, Zeszyty Naukowe Politechniki Śląskiej, Seria: Organizacja i Zarządzanie, z. 72.

Lisowska E., 2014, Różnorodność ze względu na pleć w miejscu pracy, Miscellanea Anthropologica et Sociologica, 15(1).

Listwan T., 2010, Modele i składniki strategicznego zarzadzania kadrami, [in:] Listwan T. (ed.), Zarządzanie kadrami, Wydawnictwo C.H. Beck, Warszawa.

Łukasiewicz G., 2014, Organizacyjne efekty zarządzania różnorodnościa, Prace Naukowe Uniwersytetu Ekonomicznego we Wrocławiu, nr 349.

Martin C.A, Tulgan B., 2006, Managing the generation mix. From urgency to opportunity, HRD Press Inc.

Milliken F.J., Martins L.L., 1996, Searching for common threads: understanding the multiple effects of diversity in organizational groups, Academy of Management Review, no 21.

Oleksyn T., 2014, Zarzadzanie zasobami ludzkimi w organizacji, Warszawa, Wolters Kluwer Polska.

Pant J.J., Vijaya V., 2015, Challenges in Diversity Management: a case study of MediHealth Systems, Case Study, South Asian Journal of Management, vol. 22, no 1.

Papalexandris N., Galanaki E., 2016, Business leaders of the future: demographic challenges, Athens University of Economics and Business.

Pocztowski A., 2016, Sustainable human resource management in the theory and practice, Journal of Management and Finance, no $14(2 / 1)$, pp. 303-331.

Przetacka Z., 2009, Różnorodność ze względu na wiek-zarządzanie wiekiem w organizacjach, Kobieta i Biznes, nr 1-4.

Przytuła S., Krysińska-Kościańska K., 2017, Bariery w zarządzaniu różnorodnościa kulturowa - wymiar indywidualny, grupowy i organizacyjny, Zarządzanie Zasobami Ludzkimi, nr 3-4.

Raport Firma $=$ Różnorodność, 2009, Forum Odpowiedzialnego Biznesu, Warszawa.

Rawłuszko M., 2007, Polityka równych szans a zarzadzanie różnorodnościa, [in:] Przewodnik dobrych praktyk. Firma równych szans, Gender Index, UNDP, EWUAL, Warszawa. 
Rawłuszko M., Komunikowanie w warunkach różnorodności, http://kolegia.sgh.waw.pl/p1/KGS/publikacje/Documents/ Rocznik_2009.pdf, 15.07.2017.

Rewriting the rules for the digital age. Deloitte Global Human Capital Trends, 2017, https://www2.deloitte.com/global/en/ pages/human-capital/articles/introduction-human-capital-trends.html, 15.07.2017.

Robbins S.P., 2001, Zasady zachowania w organizacji, Zysk i S-ka, Poznań.

Roberson Q.M., 2004, Disentangling the meanings of diversity and inclusion, CAHRS Working Paper Series, no 6-1,

Rogozińska-Pawełczyk A., 2016, Zarządzanie różnorodnościa spojrzenie w przyszłość, Zarządzanie Zasobami Ludzkimi, nr 3-4.

Rozkwitalska M., 2007, Różnorodność jako wartość kultury organizacyjnej na przykładzie największych korporacji transnarodowych świata, Organizacja i Kierowanie, $\mathrm{nr}$ 2(128).

Rozkwitalska M., 2011, Bariery w zarzadzaniu międzykulturowym. Perspektywa filii zagranicznych korporacji transnarodowych, Wolters Kluwer, Warszawa.

Rozkwitalska M., 2016, Relacje zawodowe z obcokrajowcami $w$ wielokulturowym środowisku pracy, [in:] Rozkwitalska M., Sułkowski Ł. (eds.), Wspótpraca zawodowa $w$ środowisku wielokulturowym, Warszawa, Wolters Kluwer Polska.

Schermerhorn J.R., 2008, Zarzadzanie. Kluczowe koncepcje, PWE, Warszawa.

Shen J. Chanda A., D’Netto B. Monga M., 2009, Managing Diversity through human resource management: an international perspective and conceptual framework, "The International Journal of Human Resource Management", no 2.

Stankiewicz K., Ziemiański P., 2012, Zarzadzanie różnorodnościa jako metoda przełamywania stereotypów i uprzedzeń dotyczacych pracowników w wieku okotoemerytalnym - przykłady dobrych praktyk, „Przedsiębiorstwo we współczesnej gospodarce - teoria i praktyka", nr 3.

Strzelczak M., 2016, Polska Karta Różnorodności-polskie wyzwania i perspektywy dalszego rozwoju, Zarządzanie Zasobami Ludzkimi, nr 3-4.

Sweeney P., McFarlin D., 1992, Distributive and Procedural Justice as Predictors of Satisfaction with Personal and Organi- zational Outcomes, The Academy of Management Journal, vol. 35 , no 3 .

Syper-Jędrzejak M., 2014, Zarządzanie różnorodnościa jako istotna kompetencja wspótczesnego menedżera, Prace Naukowe Uniwersytetu Ekonomicznego we Wrocławiu, nr 349.

Sznajder A., 2013, Przewodnik po zarządzaniu różnorodnościa, Konfederacja Lewiatan, Warszawa.

Traktat_Rzymski, https://eures.praca.gov.pl/zal/podstawy_prawne/.pdf, 16/07/2017.

Trendy HR 2017. Zmiana zasad w erze cyfryzacji, Deloitte, 2017, https://www2.deloitte.com/pl/pl/pages/human-capital/articles/raport-trendy-hr-2017.html.

Urbaniak B., 2014, Zarządzanie różnorodnościa zasobów ludzkich $w$ organizacji, Zarządzanie Zasobami Ludzkimi, nr 3-4 (98).

Walczak W., 2011, Zarządzanie różnorodnościa jako podstawa budowania potencjatu kapitalu ludzkiego organizacji, „E-mentor”, Dwumiesięcznik SGH w Warszawie, nr 3(40).

Women in boardroom, McKinsey \& Company, 2017, http://www. boardroomdiversity.org/tag/mckinsey/, 17.07.2017.

Women matter, Reinventing the workplace to unlock the potential of gender diversity, McKinsey \& Company, 2016, http:// www.mckinsey.com/france/our-insights/women-matter-2016/fr-fr, 17.07.2017.

World Economic Forum. The Future of Jobs, Employment, Skills and Workforce Strategy for the Fourth Industrial Revolution, 2016, http://www3.weforum.org/docs/WEF_Future_of Jobs.pdf, 14.07.2017.

Wziątek-Staśko A., 2012, Diversity Management. Narzędzie skutecznego motywowania pracowników, Difin, Warszawa.

Zaroda-Dąbrowska A., 2015, Zarządzanie różnorodnościa jako wyzwanie menedżerów. Wykorzystanie potencjału starszych pracowników - case study, [in:] Makowiec M. (ed.), Wybrane problemy $w$ ksztattowaniu zachowań organizacyjnych, Uniwersytet Ekonomiczny w Krakowie, Kraków.

Zarzadzanie różnorodnościa w miejscu pracy. Raport z I edycji Barometru Różnorodności, 2013, Warszawa.

Zbiegień-Maciąg L., 1997, Etyka w zarządzaniu, CiM, Warszawa.

\section{ZARZĄDZANIE RÓŻNORODNOŚCIĄ W KONTEKŚCIE ZZL}

Streszczenie: Celem artykułu jest przegląd literatury przedmiotu w zakresie prognozowanych wyzwań, przed jakimi stoją lub staną wkrótce organizacje w zakresie zarządzania różnorodnością. Autorka dokonuje przeglądu definicji terminów różnorodność i zarządzanie różnorodnością. Następnie przedstawia podejmowane działania umożliwiające zarządzanie różnorodnością z perspektywy zarządzania zasobami ludzkimi. To studium teoretyczne porządkuje materię terminologiczną z zakresu diversity management oraz proponuje racjonalizatorskie rozwiązania w odniesieniu do wybranych subfunkcji zarządzania zróżnicowanymi pracownikami.

Słowa kluczowe: różnorodność, zarządzanie różnorodnością, zarządzanie zasobami ludzkimi. 